NBER WORKING PAPER SERIES

\title{
DO STUDENTS CARE ABOUT SCHOOL QUALITY? DETERMINANTS OF DROPOUT BEHAVIOR IN DEVELOPING COUNTRIES
}

\author{
Eric A. Hanushek \\ Victor Lavy \\ Kohtaro Hitomi \\ Working Paper 12737 \\ http://www.nber.org/papers/w12737 \\ NATIONAL BUREAU OF ECONOMIC RESEARCH \\ 1050 Massachusetts Avenue \\ Cambridge, MA 02138 \\ December 2006
}

Eric Swanson provided us with the data and with help in understanding the sampling and the schooling situation in Egypt. Trey Miller provided helpful research assistance. We benefited from many useful comments and suggestions by Joshua Angrist, Mark Bils, Bruce Chapman, Paul Chen, Mark Harrison, Elizabeth King, Emmanuel Jimenez, Michele Tertilt, Martin Zelder, participants of the World Bank's Seminar on Household's Human Capital Investments, and seminars at the University of Rochester, the Australian National University, Texas A\&M, University of Wisconsin, Hebrew University, Yale University, and Cornell University. Finally, Finis Welch helped clarify some key modeling points An earlier version of this paper was presented at the Conference on Human Capital, University of Buffalo, October 26-28, 2006. The views expressed herein are those of the author(s) and do not necessarily reflect the views of the National Bureau of Economic Research.

(C) 2006 by Eric A. Hanushek, Victor Lavy, and Kohtaro Hitomi. All rights reserved. Short sections of text, not to exceed two paragraphs, may be quoted without explicit permission provided that full credit, including $\odot$ notice, is given to the source. 
Do Students Care about School Quality? Determinants of Dropout Behavior in Developing Countries

Eric A. Hanushek, Victor Lavy, and Kohtaro Hitomi

NBER Working Paper No. 12737

December 2006

JEL No. H4,I2,J2,O15

\begin{abstract}
$\underline{\text { ABSTRACT }}$
School quality and grade completion by students are shown to be directly linked, leading to very different perspectives on educational policy in developing countries. Unique panel data on primary school age children in Egypt permit estimation of behavioral models of school leaving. Students perceive differences in school quality, measured as expected achievement improvements in a given school, and act on it. Specifically, holding constant the student's own ability and achievement, a student is much less likely to remain in school if attending a low quality school rather than a high quality school. This individually rationale behavior suggests that common arguments about a trade-off between quality and access to schools may misstate the real issue and lead to public investment in too little quality. Further, because of this behavioral linkage, there is an achievement bias such that common estimates of rates of return to years of school will be overstated. The paper demonstrates the analytical importance of employing output-based measures of school quality.

Eric A. Hanushek

Hoover Institution

Stanford University

Stanford, CA 94305-6010

and NBER

hanushek@stanford.edu

Victor Lavy

Department of Economics

Hebrew University

Mount Scopus

91905 Israel

and NBER

msvictor@mscc.huji.ac.il

\author{
Kohtaro Hitomi \\ Department of Architecture and Design \\ Kyoto Institute of Technology \\ Kyoto \\ 606-8585 JAPAN \\ hitomi@kit.ac.jp
}




\title{
Do Students Care about School Quality? Determinants of Dropout Behavior in Developing Countries
}

\author{
by Eric A. Hanushek, Victor Lavy, and Kohtaro Hitomi
}

\section{Introduction}

It is a matter of faith that students and parents are concerned about school quality and take school quality into account in various other decisions, but little evidence provides convincing support for these presumptions. What evidence does exist comes from adding measures of school resources or of cognitive test performance into the behavioral models of interest. But both approaches yield biased estimates of school quality effects because both generally ignore family background and individual ability differences which themselves influence individual knowledge and skills. Moreover, direct resource measures suffer from further problems, because common school resource measures - such as per student expenditure or pupil-teacher ratio - are known to be poor proxies for differences in school quality (see Hanushek (1995, (2003) and Harbison and Hanushek (1992)). This paper employs direct measures of school quality to investigate its importance in individual decision making about school attendance.

The focus is on how school quality affects student decisions in developing countries to drop out of school, a topic of increasing importance as efforts to increase schooling levels are expanded. Almost all developing countries are rightfully concerned about the problem of low school completion rates, both because of lost investment opportunities for society and because of general inefficiency in the provision of public schooling. The Education for All initiative attached explicit schooling goals. Specifically, it emphasizes the goal that all nations ensure universal primary education by 2015 , and, while identifying school quality as a related issue, has emphasized getting all students through the early phases of schooling. ${ }^{1}$

\footnotetext{
${ }^{1}$ The Education for All movement is a global commitment to provide quality basic education for all children, youth and adults. The movement was launched at the World Conference on Education for All in 1990. Ten years later, with many countries far from having reached this goal, the international meeting in Dakar, Senegal and affirmed a
} 
This paper investigates the underlying causes of dropping out of school using a rich longitudinal data base on primary school-age children in Egypt. The central finding is that children are strongly influenced in their schooling decisions by the quality of their prospective school. This rationally-based decision implies that the traditionally perceived trade-off between access and quality may be a very bad way of viewing the policy choices. Moreover, common estimates of rates of return to schooling may give a very distorted picture of the options facing individuals and countries. The correlation of school quality and school attainment, which may also be important in more developed countries, implies that those with lower quantities of schooling could not necessarily expect to receive the incomes and investment returns of those with more schooling simply by staying in school longer.

The investment-benefit perspective on school policy concentrates on potential lost productivity from premature school dropout. Historically, high estimated rates of return to schooling have been contrasted with low school completion. Although standard methods of calculating the returns to schooling investments have been questioned in the past, virtually all available estimates indicate that schooling in developing countries has a high pay-off, especially for lower levels of schooling (e.g., Psacharopoulos (1994), Psacharopoulos and Patrinos (2004)). ${ }^{2}$

In contrast, even though schooling completion has been increasing in much of the world, it remains low in an absolute sense. In 2001, the net enrollment rate in primary education for developing countries was still only 83 percent, and this falls to 63 percent in Sub-Saharan Africa (UNESCO (2005)). The static schooling investment picture is amplified by analyses of economic growth which suggest that

commitment to achieving Education for All by the year 2015. This objective is parallel to the education portion of the UN Millennium Development Goals which also called for universal primary schooling by 2015 . For a discussion of the quality elements, see UNESCO (2005).

${ }^{2}$ Two problems are most important. First, school quality and quantity of schooling completed may be positively correlated, leading to upward biases in rates of return estimated by traditional approaches. This possibility was found to be important when analyzed in terms of both resource differences among schools (Behrman and Birdsall (1983)) and student performance differences (Harbison and Hanushek (1992)). Second, school attainment might be driven by student ability, leading to normal selection concerns (e.g., Griliches (1977)). This paper investigates both possibilities and provides strong evidence about their importance. 
human capital, as measured by school attainment, is an important determinant of the rate of economic growth across countries (e.g., Lucas (1988), Romer (1990), Barro (1991)). Thus, both viewpoints suggest that having significant numbers of students fail to complete primary schooling, let alone higher levels, is an important problem. Further, closely related to the key aspects of the analysis here, economic growth has been shown to be closely related to the quality of schooling. ${ }^{3}$

The second reason for concern about dropouts comes from a cost of education-efficiency perspective. If the objective is to get a given number of students through some level of schooling — say through the primary cycle, having students drop out earlier raises the cost of achieving the goal. ${ }^{4}$ Beyond that, large numbers of dropouts (and of grade repeaters, the related problem) may distort the normal instruction, raising the costs of schools.

While school completion levels for individuals and aggregate data on the age-grade distributions of students provide some overall sense of the dropout situation, these do not allow investigation of underlying behavioral factors or institutional structures that are driving high dropout rates. The concentration on aggregate data masks all individual specific factors, while analysis of school completion levels cannot examine time-varying family or school factors that enter individual decisions. The key to understanding dropout determinants is longitudinal data on individual students, but such panel data have rarely been available. This paper exploits a unique panel data set containing detailed information about family circumstances, schooling, and achievement for both school attenders and school dropouts from a sample of Egyptian primary schools in 1979 and 1980.

\footnotetext{
${ }^{3}$ Hanushek and Kimko (2000) find that quality measures based on international mathematics and science tests dramatically increases the explanatory power of basic cross-sectional growth models while reducing the estimated importance of average school attainment. Extensions and additions to this work by Barro (2001), Wößmann (2002, (2003), Bosworth and Collins (2003), Coulombe, Tremblay, and Marchand (2004), and Jamison, Jamison, and Hanushek (2006) all support the importance of quality differences for growth.

${ }^{4}$ Resources spent on dropouts and on grade repeaters is commonly, but misleadingly, called "wastage." Students leaving school presumably learned something and improved their skills by attending for the time they did, even if it does not achieve public outcome goals for the schools.
} 
A central feature of this analysis is the development of an output-based measure of school quality, instead of relying upon the ubiquitous input approach. The novel finding of this analysis is that students recognize quality differences among schools and act rationally in the face of such differences. This finding reinforces prior evidence on the positive correlation of quality and school attainment (Harbison and Hanushek (1992)) and casts serious doubt on the common policy debate about perceived trade-offs between wide access to schooling opportunities and developing high quality schools. ${ }^{5}$ Complete consideration of optimal investment in school quality requires information about the costs of improving quality, but, even in the absence of cost information, it is clear that the usual returns to quantity of schooling are biased upwards.

\section{Egyptian Schooling}

With some 16 million students, the Egyptian education system is one of the largest in the Arab world. While making substantial improvements over the past decade in primary education, Egypt still faces problems of both attainment and quality.

Pre-university education in Egypt is divided into 3 levels. Egyptian children enter primary school at age 6 and transition to a 3-year preparatory school. The Egyptian government characterizes these first two levels as basic education, and state law mandates attendance as compulsory at those levels. On-track Egyptian students subsequently transition to a 3-year secondary school. Net enrollment rates for primary education (grades 1-5), the preparatory level (grades 6-8), and the secondary level (grades 9-12) are 97 percent, 74 percent, and 65 percent, respectively.

The Egyptian school system developed considerably during the 1990s. Egypt, like many developing countries, has historically faced significant challenges with regards to school enrollment. For

\footnotetext{
${ }^{5}$ This finding also contrasts with the mixed prior evidence about the impacts of school quality on dropouts and school completion (Glewwe and Kremer (2006)). Prior studies use varying observed measures of school characteristics to measure quality, and these are inconsistently related to school attainment decisions.
} 
many years, state law required compulsory education through the sixth grade. However, as late as 1991, primary school enrollment represented only 80 percent of the corresponding age cohort (World Bank (1991)). During the 1990s, funding to primary and secondary education was increased, in part by redirecting funds previously going to tertiary education. A substantial school construction program provided for universal access to primary education by the turn of the century.

Egypt has employed a top-down approach to education. Funding is determined at the national level and allocated to the State Ministry of Education (MOE). The MOE chooses statewide curricula, purchases textbooks and allocates funds and teachers to individual schools according to official enrollment counts. Although recent grassroots efforts have begun to alter this top-down model, leading to the creation of Parent Teacher Associations and other forums for local involvement, the balance of power still overwhelmingly resides at the national level. For this reason, it is reasonable to take the budget and resources available to individual schools as exogenous for estimation purposes.

Egyptian policymakers have also had longstanding concerns over equity in the state-run education system. In particular, rural students and females have consistently suffered lower school enrollment rates than their urban and male counterparts. For example, from 1966-1986, the female enrollment in Egyptian primary schools remained constant at $45 \%$ of total enrollment, and was as low as $10 \%$ of total enrollment in some outlying areas (World Bank (1991)).

The Egyptian government, in cooperation with the World Bank and other development organizations, has worked to alleviate many of the above concerns, and their efforts have been quite successful. By 2001, Egyptian primary school enrollment had reached 97 percent, and the female enrollment rate had largely caught up with that of males. Moreover, a large-scale intervention aimed at building primary schools in outlying areas made primary school accessible to 99 percent of rural Egyptians by 2001 (World Bank (2002)). 
While the Egyptian educational system has made great progress in recent years, many areas of concern have yet to be addressed. Access to primary school is largely universal, but many Egyptians fail to take advantage past the compulsory years. The dropout rate is particularly high at transition stages. The transition rate from the compulsory preparatory school to secondary school was 81 percent in 2001 (World Bank (2002)). Due to significant tracking in the secondary school system, transitions from secondary school to the Egyptian higher education system vary widely. The transition rate for those in the academic track is 91 percent, while the rate for those in the vocational track is only 8 percent (World Bank 2002).

Another related source of concern that may be feeding the dropout rates is the large emphasis on private tutoring in Egypt. There is a long tradition in Egypt of parents paying for private lessons to complement regular schooling and, especially to assist in studying for the exams that determine placement in the desired academic track. This tradition places poor children, whose parents are unable to pay for such lessons, at a significant disadvantage and is seen by many as a major source of inequity in the Egyptian educational system (World Bank (2002)).

The differential in enrollment by income is clear. Of children age 6-15, 86 percent of nonpoor are enrolled compared to only 77 percent of the poor. Related to the analysis here, the United Nations (2004) review of education under the MDG states: "Low quality and low achievement among the poor produce limited learning and thus limited expected economic returns, especially when compared to the rising household cost of education."

\section{Overview of the School Dropout Model}

The central focus of this work is the dropout decision of primary school students. Dropout decisions are directly related to school completion, but concentrating on these decision points permits more accurate characterization of the various time-specific factors underlying the behavior. And, while 
all students will eventually drop out of school, there is a clear prima facie case that doing so during the primary grades is nonoptimal from either a public or private viewpoint.

The opportunities facing the student both in and out of school are important to understanding school leaving. The underlying conceptual framework here is a simple optimization model on the part of the student. The student is seen as maximizing lifetime utility through the choice of schooling level. A key element of this choice is the earnings opportunity of the student, which is a function of the past and future schooling experiences of the student. This section presents the underlying theoretical model of school choice with quality variations. The subsequent section describes the empirical implementation and estimation strategy.

The maximization of lifetime income with respect to years of schooling is a straightforward optimization problem that has been solved in various contexts. While details vary depending on the structure of the problem analyzed, the key idea is trading off foregone current earnings for enhanced future earnings.

$$
\begin{aligned}
\max \Psi & =\int_{0}^{T} e^{-r t}\left[Y_{t}\left(H_{t}, Z_{t}\right)-c(t)\right] d t \\
& =\int_{0}^{S} e^{-r t}\left[Y_{t}\left(H_{t}, Z_{t}\right)-c(t)\right] d t+\int_{S+1}^{T} e^{-r t} Y_{t}\left(H_{t}, Z_{t}\right) d t
\end{aligned}
$$

Income $(\mathrm{Y})$ is a function of human capital $(\mathrm{H})$ and other factors $(\mathrm{Z})$ affecting wages and earnings. $\mathrm{c}(\mathrm{t})$ is the direct costs of schooling in each period. In order to concentrate on the schooling investment, the maximization problem is separated into a schooling period $(\mathrm{S})$ and a post-schooling period. $\mathrm{T}$ is the relevant time horizon, assumed to be known and fixed; $r$ is the discount rate.

Investment in human capital involves not only schooling but the quality of that schooling, an individual's ability and prior achievement, and prior human capital accumulation. Thus, in discrete form and ignoring any depreciation, 


$$
H_{t}=H_{t-1}+h\left(s_{t}, q_{t}, X_{t}, g, A_{t-1}\right)
$$

where $\mathrm{s}_{\mathrm{t}}$ is the quantity of schooling, $\mathrm{q}_{\mathrm{t}}$ is school quality, $\mathrm{X}$ is other factors affecting human capital including family inputs, $\mathrm{g}$ is innate ability, and $\mathrm{A}_{\mathrm{t}-1}$ is prior achievement. It is natural to think that the value of schooling in human capital production is enhanced with higher quality schools, with greater family inputs, with higher ability, and with more prior achievement. School attainment by itself is not a complete measure of human capital — an issue to which we come back.

As it stands, however, this investment model is not easily implementable for empirical analysis. The simple formal analysis is conducted for an individual and ignores most personal and family factors that might interact with the rate of return derived from market work. It is frequently just assumed that it is possible to employ this analytical structure related to individual stopping rules to explain differences in schooling across individuals, but the appropriateness of such a step deserves consideration. First, it is necessary to characterize nonschool factors that might enter into such schooling decisions, and the theoretical works seldom address these. Second, the relevant rate of return, $i_{s}$, pertains to each individual, and there is a presumption that this varies across individuals (consistent with variations in school completion in the population). Clearly, if $i_{s}$ is constant for individuals, variations in the choice of schooling level will be determined completely by considerations other than the foregone and future earnings opportunities that are included in the rate of return calculations. Yet, dealing with this is difficult and seldom undertaken explicitly. ${ }^{6}$ Typically, information is available on only the average returns to schooling across groups of individuals, and any variations across individuals occur in highly structured ways. Even average earnings opportunities facing individual students may be difficult to

\footnotetext{
${ }^{6}$ There are, of course, important exceptions. Theoretically, Becker (1975) considers individual variations in costs and benefits in describing the distribution of individual schooling decisions. This discussion is further developed in Card (1999). Empirically, Willis and Rosen (1979) consider individually varying returns to different amounts of schooling. A thoughtful discussion and interpretation of existing work is found in Willis (1986). A broad critique of alternative approaches to estimating the return to schooling is found in Heckman, Lochner, and Todd (2006).
} 
characterize, because of thin markets and of significant selection problems, and it may be difficult to separate current from future earnings to the extent that they both vary by individual characteristics and by local labor markets.

With perfect capital markets, the central result for schooling choices can generally be summarized by a simple optimal stopping rule for an individual: everything else equal, continue investing in schooling until $i_{s}$, the rate of return for s years of schooling, falls below the market interest rate on alternative investment options. With borrowing constraints or imperfect capital markets, the magnitude of foregone earnings and of family wealth and income could also separately influence decision making, because some families may not be able to take advantage of high rates of return that involve large up-front costs.

Finally, and central to this discussion, it has been common to assume that schooling is homogeneous and directly measured by the length of time spent in school. Such an assumption, which greatly simplifies analysis by restricting attention to just the quantity margin, implies that the schooling investment decision is unrelated to quality differences among programs. On the other hand, it seems likely from the individual decision making view that there will be interactions of school stopping rules with quality. If school quality differs and if student performance has important subsequent implications for the labor market, one would expect variations in student dropout decisions to be directly related to the quality of the school. Where the costs of schooling come through foregone earnings, higher quality schooling is cheaper (holding constant prior achievement and ability), and this would be expected to induce more investment in schooling by the individual. This relationship is exactly the one central to this paper. The more learning during any period of time, the more likely it is that a student will continue in school rather than dropout. This must be incorporated into empirical analysis. ${ }^{7}$ Clearly, any

\footnotetext{
${ }^{7}$ Similar problems arise with individual ability. Extensive work on "ability bias" in wage-schooling equations treats measured achievement or ability as fixed and independent of schooling (see, e.g., Griliches (1977)). With individual student abilities, the impact on school decisions depends on the relative strength of ability on subsequent school performance and on market opportunities. The original Ben-Porath (1970) formulation of the school investment
} 
consideration of the dropout problem that ignores school quality also contrasts sharply with the policy debate, where attention invariably concentrates on potential decisions about resources and quality for schools at different levels and in different areas.

\section{Empirical Implementation}

We begin by thinking of an empirical structure with schooling investments and their achievement effects and with school dropouts. The achievement formulation (Equation 3) follows from commonly employed educational production function estimation. ${ }^{8}$ This estimation is matched with a model indicating the inherent dropout propensity (D*), Equation 4.

$$
\begin{gathered}
A_{i t}=f\left(X, F_{A}\right)+\gamma_{A} A_{i t-1}+\sum_{s} \delta_{s} S_{i s t}+\varepsilon_{i t} \\
D_{i t}^{*}=g\left(W, F_{D}\right)+\gamma_{D} A_{i t-1}+\lambda\left(\sum_{s} \delta_{s} S_{i s t}\right)+v_{i t}
\end{gathered}
$$

where $F_{A}$ and $F_{D}$ are family inputs, and $X$ and $W$ are exogenous influences on $A$ and $D$, respectively. $S_{\text {ist }}$ is an indicator that equals one if student $\mathrm{i}$ attends school $\mathrm{s}$ in year $\mathrm{t}$ and equals zero otherwise. Thus, $\delta_{s}$ has the natural interpretation of the quality of school s, and $\lambda$ indicates how sensitive the dropout decision is to school quality. (This formulation can alternatively be described as a fixed effect estimator for schools).

Virtually all past analyses of school attainment, drop-out behavior, and the like ignore any quality differences across schools, essentially presuming that a year is a year when it comes to schooling. Those studies addressing school quality, particularly the effects of school quality on other behavioral outcomes

decision separates ability and achievement and treats additions to individual human capital (which might be interpreted as school related achievement) as neutral, i.e., equally potent in the market and in school. While convenient for modeling purposes, there is little prior empirical evidence on this neutrality proposition.

${ }^{8}$ See Hanushek (1979). 
of interest, most commonly employ simple input measures of quality. For example, it is common for various labor market investigations to include expenditure per pupil or measures of real resources (e.g., average class size or teacher credentials), if they include anything about quality. ${ }^{9}$ Both approaches are inappropriate. Achievement differences among students are large, and direct analyses of earnings opportunities of workers suggest that differences in cognitive skills may be very important in determining earnings alternatives. ${ }^{10}$ The inappropriateness of input measures of school quality is examined and reviewed in Harbison and Hanushek (1992) and Hanushek (2003).

The approach here is to estimate directly variations in school quality, based on student outcomes in different schools. School quality here is defined simply as the gain in achievement that a student can expect from attending a given school for an additional year. This outcome-based perspective, which contrasts sharply with most other research, permits analysis of the effect of school quality on individual student decisions about remaining in school.

The estimation of school quality follows a very simple value-added model of achievement. Current achievement $\left(\mathrm{A}_{t}\right)$ is viewed as a function of inputs both from the family $\left(\mathrm{F}_{\mathrm{A}}\right)$, from peers and individual differences $(\mathrm{X})$, and from schools $\left(\mathrm{S}_{\mathrm{S}}\right)$. The importance of nonschool inputs in the achievement relationship shows vividly why the common reliance on just school attainment in earnings

\footnotetext{
${ }^{9}$ See, for example, Card and Krueger (1992) and Betts (1996) and the critiques in Heckman, Layne-Farrar, and Todd (1996) and Hanushek, Rivkin, and Taylor (1996).

${ }^{10}$ Analyses of earnings differences and cognitive skills are most readily found in developed countries and particularly the United States, although a number also exist for developing countries. For developing countries, see Glewwe (1996), Jolliffe (1998), Vijverberg (1999), Boissiere, Knight, and Sabot (1985); Knight and Sabot (1990), Angrist and Lavy (1997), Moll (1998), and Behrman, Ross, and Sabot (forthcoming). For developed countries, The clearest analyses are found in the following references (which are analyzed in Hanushek (2002)): Bishop (1989, (1991); O'Neill (1990); Grogger and Eide (1993); Blackburn and Neumark (1993, (1995); Murnane, Willett, and Levy (1995); Neal and Johnson (1996); Mulligan (1999); Murnane, Willett, Duhaldeborde, and Tyler (2000); Altonji and Pierret (2001); Murnane, Willett, Braatz, and Duhaldeborde (2001); and Lazear (2003).
} 
models is incomplete, even if school quality is roughly constant. Finally, prior achievement $\left(A_{t-1}\right)$ is included to capture unmeasured prior school inputs and ability differences. ${ }^{11}$

Equation (3), the basic value-added form, offers considerable simplification for both data collection and estimation. With this formulation, one need observe just past achievement and the intervening school and family inputs. Past work has demonstrated that differences in schools are very important but does not provide any clear indication of how school quality can be reliably measured (see the summary in Harbison and Hanushek (1992)). Therefore, the approach here is to estimate conditional achievement growth differences across schools.

The dropout model in Equation 4 provides a formulation of how school quality and other factors affect dropout propensities. Of course, D* is not observed. Instead, we simply observe whether or not somebody has dropped out of school. We assume that $v_{i t}$ in Equation 4 is normally distributed and that a person is observed to dropout when $\mathrm{D}^{*}>0$ and to remain in school when $\mathrm{D}^{*}<0$. This specification implies that the dropout equation is a probit problem.

The parameter of interest in Equation 4 is $\lambda$, the effect of school quality on dropout probabilities. This provides direct estimates of how varying school quality affects individual stopping decisions on schooling. The key element of this is that individual specific factors of ability, own achievement, and parental factors (including wealth and income to control for borrowing constraints) are incorporated in $\mathrm{g}(\mathrm{W}, \mathrm{F})$ - so this is the effect of school quality after allowing for individual differences in performance.

\footnotetext{
${ }^{11}$ An alternative approach is simply to analyze $\Delta A$, which effectively constrains $\gamma_{A}$ to one. We do not impose that constraint here for several reasons. First, in actual application it is common to employ test measures of achievement, and these test measures are not necessarily based on the same scale of measurement; provides the appropriate rescaling. Second, the impact of past inputs may decline over time, implying, say, that the impact of the first grade teacher may be more important in determining first grade achievement than third grade achievement. Third, gains in achievement may be more difficult to obtain as achievement grows, implying some decreasing returns to initial achievement levels. (In the latter two situations, Equation 3 will include a more complicated error structure, and the potential estimation difficulties posed by this are addressed below). The interpretation of alternative estimation forms is discussed in Rivkin (2005).
} 
The basic approach to the empirical application is the simultaneous estimation school quality and dropout behavior using maximum likelihood. By this joint estimation, we not only obtain appropriate standard errors that reflect the simultaneous estimation of school quality but also permit correlation of the errors across equations. This latter aspect deals directly with any selection of dropping out that could bias the estimates of school quality. At the same time, we also provide OLS and instrumental variables estimators of the school quality equation. These alternative estimates both correspond to other readily available estimates and get around problems of any contamination through specification problems in the dropout equation, at the expense of some stronger assumptions about the nature of the stochastic terms in Equation 2.

\section{Estimation Samples}

The empirical analysis employs data collected in a longitudinal survey of primary school students in Egypt during two academic years, 1978/79 and 1979/80. The survey was part of the Egyptian Retention Study financed by the World Bank. The principal objective of the study was to examine skill retention among dropouts with special attention directed at urban/rural and male/female differences. Three key elements of the data base make it uniquely well-suited to our task: 1) the provision of repeated observations on children of primary school age; 2) the collection of data on children both in and out of school; and, 3) the extensive testing of children, both in and out of school, to determine their cognitive achievement and ability.

The 1978/79 sample was drawn from a two-stage stratified sample of primary school students and dropouts. ${ }^{12}$ Beginning with a random sample of 30 urban and 30 rural primary schools, random samples of students currently attending grades three through six and dropouts who had attended the same grades

\footnotetext{
${ }^{12} \mathrm{~A}$ complete description of the background for the data collection along with the details of sampling can be found in Swanson (1988).
} 
between 1975 and 1978 were selected. Sampling rates for schools and students varied with the rural/urban location of the school. Nominal sampling rates for dropouts from the sample schools were set at 100 percent. The realized sample included 8,570 usable observations on test scores. In addition, 1,808 dropouts of an estimated 2,747 were located and included in the sample.

In the second year, a one-third subsample of the 1978/79 sample was drawn within each sampled school. The in-school sample was taken from those who continued in school in fourth, fifth, and sixth graders in the 1979/80 school year, dropping students who had completed the sixth grade during the first survey year. In total, 1,976 students were both located and tested in the 1980 follow-up. The corresponding 1979/80 dropout sample consisted of all members of the previous dropout sample that could be relocated and tested in 1980. Further, all "new" dropouts (from school year 1978-79) and any additional "old" dropouts (who had not been located in the previous year) were included. In total, 1,725 dropouts were included in the 1979-80 sample.

Seven skill-specific achievement tests and two ability, or "intelligence," tests were developed for the survey. The two intelligence tests were intended to capture non-curriculum dependent measures of the child's skills. In the first year, all nine tests were assigned to the dropout sample, while inschoolers were assigned only those tests considered appropriate to their grade level. ${ }^{13}$ In 1979/80, all nine achievement and intelligence tests were assigned to every member of the sample.

In addition to the achievement tests, four questionnaires were employed in 1978-79 to collect information about students, their families, their schools and their associated community. In the second

\footnotetext{
${ }^{13}$ There are four literacy skill tests: Reading A and Reading B measure reading skills; Writing A and Writing B require the child to write words, sentences, and, finally, an entire paragraph. The three numeracy tests included: a simple operations test ( 28 problems), a problem solving test (fourteen "story" problems), and an elementary geometry test (eight problems). The tests were designed to be appropriate for different grade levels: the Reading A, Writing A, simple operations and problem solving tests given children in grade 4 or lower; the Reading B, Writing $\mathrm{B}$, and the three mathematics tests were given in the higher grades. Testing was done in one session. Inschoolers were tested in their classrooms during regular school hours, while dropouts were brought to school for special sessions. For details, see Swanson (1988).
} 
year two additional questionnaires were used to collect information about the child's school record, family background, work experience and attitudes towards school.

These basic samples are combined to create the student panel data employed in the empirical analyses. The descriptive statistics for the subsequent analytical samples are found in Appendix Table A1.

\section{Basic Empirical Results}

The school quality and dropout models have been estimated simultaneously with maximum likelihood techniques. Here we describe the results from each separately.

\section{A. School Quality.}

The focus of the school quality modeling is estimation of expected achievement gains in individual schools (holding constant variations in individual achievement, family background, and the like). This estimation is carried out in three different ways. First, the basic value-added relationship of Equation 3 is estimated by ordinary least squares, mirroring the common approach to estimating achievement relationships. Second, instrumental variables are employed to deal with potential endogeneity of initial achievement in Equation 3. Third, maximum likelihood is used to estimate the achievement and dropout equations simultaneously. This latter analysis deals with the potential impact of student selection on the estimation of school quality, but it employs a smaller sample and it does not deal with the endogeneity issues for initial achievement. Therefore, it is useful to compare these alternative approaches, each of which has both strengths and weaknesses.

The OLS estimates of the value-added achievement relationship raise concerns about both the accuracy of measurement of prior achievement $\left(\mathrm{A}_{\mathrm{t}-1}\right)$ and the possibility that prior achievement is 
correlated with the error in the equation $\left(\varepsilon_{i t}\right) .{ }^{14}$ The faulty measurement of prior achievement can be thought of as arising from observations $\left(\tilde{\mathrm{A}}_{\mathrm{t}-1}\right)$ that differ from the true achievement by a random error, $\xi_{i t}$, as described in Equation (4):

$$
\widetilde{A}_{i t}=A_{i t}+\xi_{i t}
$$

The presence of such measurement error will generally lead to biased estimates of all of the parameters in Equation (3), even when $\xi_{i t}$ has mean zero. This situation is frequently hypothesized because of the widespread impression that individual achievement measurement is difficult and subject to considerable uncertainty. Alternative treatments for dealing with this problem are generally available, including direct correction of the measurement error variance and the use of instrumental variables. ${ }^{15}$ The second concern is that $\varepsilon_{i t}$ will be correlated with $\mathrm{A}_{\mathrm{t}-1}$ when the $\varepsilon_{i t}$ 's are correlated over time. Such correlations, which could result from unmeasured individual or family factors that are not captured $\mathrm{F}_{\mathrm{A}}$ also lead to inconsistent estimates of the model's parameters. Again, however, if suitable instruments for $\mathrm{A}_{\mathrm{t}-1}$ can be found, it is possible to correct the estimation for these problems of endogeneity. In the simple measurement error model of Equation (5), the independent information on measured student ability can be used as an instrument, assuming that any errors in measuring ability are generated by a different process than those in measuring achievement but that true ability and true achievement are correlated. An alternative perspective concentrates on the identification problems arising from serially correlated

\footnotetext{
${ }^{14}$ Both of these problems could be avoided if it were plausible to constrain the parameter on $\mathrm{A}_{\mathrm{t}-1}$ to equal one so that the achievement model could simply be estimated in terms of $\Delta A$. But, as described above, this is likely to be inappropriate in the context of the achievement models considered here.

${ }^{15}$ Note that measurement error in current achievement, $A_{t}$, can be subsumed in the equation error and generally causes no special statistical problems. If the variance of the measurement error is known, the estimation can directly incorporate this, yielding consistent estimates of all parameters. While information about measurement error is rarely available, the special characteristics of test measures of achievement at times provide this possibility through use of test reliability estimates. When done in the past, however, it has not led to significant changes (Hanushek (1992)).
} 
equation errors. One approach to this uses data on characteristics of prior teachers (1978-79) as instruments for $\mathrm{A}_{\mathrm{t}-1}$. Specifically, the years of experience, qualification level, and seniority in school of the 1979 teacher are employed as instruments, although past work suggests that these measured characteristics imperfectly measure teacher quality differences. For this analysis, we simply combine both the measurement error and serial correlation models to produce the IV estimates in column 2 of Table 1.

The OLS and IV approaches relies on the "school quality" sample made up of 2,431 students, which represents all 1979-80 inschoolers with usable test scores in both years and with complete background data. ${ }^{16}$ Variable definitions and descriptive statistics are found in Appendix Table A1. Six percent of the students are at grade three, 42 percent at grade four, 33 percent at grade five and the rest at grade six in 1980. The sum of the scores on the Reading A and simple operations tests are our measure of the student's scholastic achievement. The mean achievement score is 20.8 in 1979 and 26.2 in the following year. The MLE estimates employ a sample that eliminates the sixth grades (because of imperfect measurement of dropout status). This restricted sample with 1,710 cases is also described in Appendix Table A1.

Table 1 displays estimates of the basic value-added achievement model estimated in log-log form. The estimation IV methodology has its largest effect on the estimated coefficient for $A_{t-1}$. This is expected because both potential problems would be expected in this situation to bias this parameter toward zero. Nevertheless, even in the IV model, the estimated coefficient on prior achievement is

\footnotetext{
${ }^{16}$ These sample sizes are subsequently reduced in the instrumental variables estimation because of missing data for the instruments. See Table 1, below.
} 
Table 1. Achievement Value Added Models: 1980

(Dependent Variable: LnACHIEVE $t$; t-statistics in parentheses)

\begin{tabular}{|c|c|c|c|}
\hline & \multicolumn{3}{|c|}{ Estimation methods } \\
\hline Input & OLS & $\mathrm{IV}^{\mathrm{a}}$ & $\mathrm{MLE}^{\mathrm{b}}$ \\
\hline $\operatorname{LnACHIEVE}_{\mathrm{t}-1}$ & $\begin{array}{c}0.548 \\
(33.64) \\
\end{array}$ & $\begin{array}{c}0.767 \\
(23.30)\end{array}$ & $\begin{array}{c}0.53 \\
(34.32)\end{array}$ \\
\hline Grade 4 & $\begin{array}{l}0.353 \\
(7.52)\end{array}$ & $\begin{array}{r}0.181 \\
(3.38) \\
\end{array}$ & $\begin{array}{l}-.012 \\
(-0.4) \\
\end{array}$ \\
\hline Grade 5 & $\begin{array}{l}0.416 \\
(8.42)\end{array}$ & $\begin{array}{l}0.163 \\
(2.71)\end{array}$ & $\begin{array}{c}.040 \\
(1.06) \\
\end{array}$ \\
\hline Grade 6 & $\begin{array}{l}0.280 \\
(5.43)\end{array}$ & $\begin{array}{l}0.026 \\
(0.42)\end{array}$ & \\
\hline Mother's Education & $\begin{array}{l}0.002 \\
(0.17)\end{array}$ & $\begin{array}{l}-0.006 \\
(-0.74)\end{array}$ & $\begin{array}{l}-.0025 \\
(-0.20)\end{array}$ \\
\hline Father's Education & $\begin{array}{l}0.008 \\
(2.25) \\
\end{array}$ & $\begin{array}{l}0.009 \\
(1.60)\end{array}$ & $\begin{array}{l}.006 \\
(1.5)\end{array}$ \\
\hline Constant & $\begin{array}{c}1.371 \\
(16.17) \\
\end{array}$ & $\begin{array}{r}0.883 \\
(7.76) \\
\end{array}$ & $\begin{array}{r}2.528 \\
(38.72) \\
\end{array}$ \\
\hline $\begin{array}{c}\text { F-test } \\
\text { School equality }\end{array}$ & 7.25 & 6.41 & \\
\hline $\mathrm{R}^{2}$ & 0.55 & 0.52 & \\
\hline observations & 2431 & 2167 & 1714 \\
\hline School dummies & yes & yes & yes \\
\hline
\end{tabular}

Notes:

a. Combined measurement error and endogeneity: ln Ability $\mathrm{y}_{\mathrm{t}-1}$ and teacher
characteristics as instruments.

a. Maximum likelihood estimates jointly estimated with drop-out model. 
significantly different from one, implying that simple differencing of achievement would be inappropriate in this context. ${ }^{17}$

There is limited evidence suggesting that parental background systematically affects achievement growth, or value-added. Father's education level shows a positive effect on student performance but the estimated effect is uniformly small. Mother's education is always small and statistically insignificant. In this sample, however, the level and variation of parental education, particularly mother's education, is extremely limited. Preliminary estimation included a wider range of characteristics of the family (income, wealth, and family size), but none proved to be significant and only the more parsimonious results are presented here. This of course does not imply that differences in family inputs are totally unimportant. Their impact on achievement growth rates cannot be detected, but family factors clearly enter into the starting level of achievement, $A_{t-1}$.

The key finding of this estimation is that sampled schools are clearly very different in terms of quality. The precise quantitative estimates of school quality vary somewhat with the estimation method, although they are very highly correlated. The estimated quality measures from the simple OLS estimates (col. 1) and the instrumental estimates (col. 2) have a simple correlation of 0.92 , and, perhaps more importantly, the identification of the top and bottom quartiles of schools is very consistent across estimation method. The OLS and the MLE estimates have a correlation of .69. The F-statistics in Table 1, against the null hypothesis of homogeneous schools, confirm that there are significant differences among the sampled schools.

The estimates indicate that growth in achievement can be dramatically different depending on the specific school. Table 2 displays descriptive statistics for the IV and the MLE estimates of school quality variations. These are presented for all schools and for schools divided by urban and rural location. While

\footnotetext{
${ }^{17}$ Other work (not shown) separates the two IV approaches (measurement error and serial correlation of the equation errors). The imprecise estimate of the coefficient on prior achievement (and the other coefficients in the model) with just prior teacher characteristics suggests, however, that these are relatively weak instruments.
} 
Table 2. Distribution of Estimated School Quality

\begin{tabular}{|c|c|c|c|}
\hline \multicolumn{2}{|c|}{ All schools } & Rural & Urban \\
\hline \multicolumn{2}{|c|}{ IV estimates ${ }^{\mathrm{a}}$} & \multicolumn{2}{|c|}{} \\
\hline Mean & -.084 & -.111 & -.057 \\
\hline Minimum & -.62 & -.62 & -.52 \\
\hline Maximum & .30 & .30 & .21 \\
\hline MLE estimates & & & -.048 \\
\hline Mean & -.062 & -.077 & -.28 \\
\hline Minimum & -.43 & -.43 & .17 \\
\hline Maximum & .40 & .40 & \\
\hline
\end{tabular}

Notes: School quality is measured as proportional deviations from Taha Hussein School

a. School quality estimates from column 2, Table 1.

b. School quality estimates from column 3, Table 1. 
the estimation approaches produce slightly different patterns, the overall picture is quite consistent. The range is instructive: By the IV estimates, one school has 30 percent higher achievement growth than the base school while, at the other end of the range, we find a school that has about 62 percent lower growth; ${ }^{18}$ by the MLE estimates, the range is 40 percent higher to 43 percent lower. These estimates imply that one year in the best school can be equivalent (in expected achievement gain) to more than two years in the worst school. This magnitude of difference obviously can have a huge effect on the achievement of a student when compounded over just primary schooling, and it implies that the rate of return to a year of individual schooling investment could vary systematically.

Table 2 also indicates that the average quality of urban schools is some 3-5 percent above that of the sampled rural schools. Nevertheless, the distributions show considerable overlap with both the best school and the worst school identified as being in the rural areas. Thus, it is inappropriate to assume that urban schools are "good" and that rural schools are "bad."

These differences are interpreted as reflecting quality variations in the schools, even though the underlying characteristics of teachers and schools that are important are not identified. This implicit measurement raises the possibility that the estimated effects involve more than just school effectsimportantly, that they might include some individual student effects or some community effects. Several additional pieces of evidence support the school quality interpretation.

First, school expenditure is reasonably considered as exogenous, given the nature of funding by the central government. Attendance at public schools is geographically determined by residence location. For rural areas, this implies virtually no Tiebout-like choice, especially given the absence of a private

\footnotetext{
${ }^{18}$ The estimation in the table presents estimates as deviations from the Taha Hussein urban school. Since all that can be estimated is variations across schools, it does not matter which school is chosen as the basis for comparison. Note that, when achievement is measured in logarithms, the school-specific coefficient (times 100) is approximately the percentage deviation from the base school. With the OLS estimation, the range of the school quality estimates is virtually identical, going from -.38 to +.39 .
} 
sector. For urban areas, some choice of location is possible, but the central funding, curriculum, and decision making lessens its importance.

Second, because of the geographic basis of schools, it is possible that other community factorsfrom intensity of schooling preferences to health and nutrition characteristics - are the key feature but are confounded with schools through the estimation strategy. As a test of this, we correlated average mother's education and average father's education for all students in the school with school quality. We hypothesized that parental education would be an important determinant of any broader community factors as well as the ability of parents to identify and act on such differences. Average mother's and father's education were correlated -0.027 and +0.045 , respectively, with our IV measure of school quality $\left(\delta_{s}\right)$, although it is closer to 0.2 in the MLE estimates.

Third, the individual ability factors are assumed to enter into the level of achievement but not growth, so the school effects might just be a measure of having a collection of smart students. As a crude test of this, we calculate the correlation between our estimated school quality and the mean level of 1979 achievement in the school. ${ }^{19}$ The simple correlation is only .099, insignificantly different from zero. (This finding also suggests that the school quality differences are not just peer effects but instead more reflect aspects of teachers and schools).

Fourth, we have compared our indirect estimates of school quality with those from direct estimation employing explicit measures of school quality. Specifically, we first estimate individual level, value-added achievement models where we substitute explicit measures of teacher and school

\footnotetext{
${ }^{19}$ Ordinary least squares techniques will imply that individual parental education and achievement in 1979 will be uncorrelated with the error terms in the equations for the total sample. Here, however, we are concerned with the correlation of the school-level aggregate of 1979 achievement and parents' education with the school level average growth in achievement, and these correlations are not constrained by the estimation.
} 
characteristics for the covariance structure in Equation (2). ${ }^{20}$ We then create teacher quality and school quality indexes by aggregating average teacher and school characteristics according to the coefficients from these models. Finally, we regress our measure of IV estimates of total school quality on these two indexes. Each index is positively correlated with our measure, although the teacher index is insignificantly different from zero. ${ }^{21}$ The $\mathrm{R}^{2}$ is 0.16 , indicating some relationship of school characteristics but also much that is left out. Thus, our measure goes considerably farther in capturing important other dimensions of quality.

We take these further tests as justification for interpreting the variation in school fixed effects as variation in school quality. It is difficult in these analyses to rule out all other interpretations, and exogenous instruments that do not enter directly into the achievement models are virtually impossible to find. Nonetheless, all of the evidence points toward a school quality interpretation.

The OLS and IV estimates are obtained from the sample of students who remain in school over both years. While the samples are large, over 2,100 students in the 60 schools, it is possible that missing test scores for the dropouts could bias these estimates. Specifically, if a school had a large dropout rate and if dropouts were the lowest growth achievers (in the value added models), its aggregate gain in average student performance could be pushed up relative to a school with a low dropout population. On the other hand, the MLE models are estimated to take such a possibility into account. This selection correction may be a partial explanation for the imperfect correlation between the IV and MLE estimates of school quality, although the different samples undoubtedly also contributes.

\footnotetext{
${ }^{20}$ These models include the individual characteristics in Table 1 plus four teacher variables (sex, age, schooling, and experience) and four school variables (school wealth measured by facilities, availability of desks, availability of boards, and class size).

${ }^{21}$ The estimated equation is: $\delta_{\mathrm{s}}=-.22+1.31 \mathrm{TI}_{\mathrm{s}}+0.79 \mathrm{SI}_{\mathrm{s}} \quad$ where $\mathrm{TI}=$ teacher index; $\mathrm{SI}=$ school index. (1.2) (3.0) $\mathrm{n}=59 \quad \mathrm{R}^{2}=.16$ (t-statistics in parentheses)
} 
The presumption in subsequent section is that these estimates $\left(\delta_{s}\right)$ accurately reflect quality differences among schools and that students and their parents can gauge the differences that exist.

\section{B. School Dropout Behavior.}

The final and most important component of the estimation looks specifically at the dropout decision. Beginning with the sample of all in-school children in 1979, we attempt to understand why some dropout by 1980 while others remain in school. All sixth graders are eliminated from the sample because it is not possible to distinguish between those who drop out of school and those who go on to another school (a common occurrence at this grade). The estimation sample of 1,714 students includes both students who remained in school in 1979/80 and those who dropped out (4.2 percent) in that year. The share of urban and female students in this sample is higher than in the earnings sample which relied on sampled dropouts since 1975.

Figure 1 presents raw dropout rates plotted against the estimated school quality using the IV estimates. While the dropout estimation is done by joint estimation with MLE, we provide the independent quality and dropout evidence here so that there is no necessary statistical link between the quality estimates and drop out behavior. There is an unmistakable fall in drop out rates as school quality increases. ${ }^{22}$ The relationship is also more obvious among the rural schools (not separately shown), where dropping out tends to occur earlier and frequently.

We present MLE probit models of dropout determinants (Equation 3) in Table 3. The difference between the two columns is the estimation form for the achievement models. Column 1 excludes $\log$ of measured 1979 ability from the achievement function while column 2 includes it. The estimates are nonetheless extremely similar and do not require separate discussion.

\footnotetext{
${ }^{22}$ As mentioned previously, one concern with the IV estimates (but not the MLE estimates) is that higher dropout rates would tend to bias upward the estimates of school quality if drop outs were the lower achievement growth students. But, if this is the case, the bias would work against the hypothesis that lower quality schools induce more drop outs. In other words, the observed relationship should be even more pronounced than it is.
} 
Fig. 1 -- Raw dropout rates and school quality

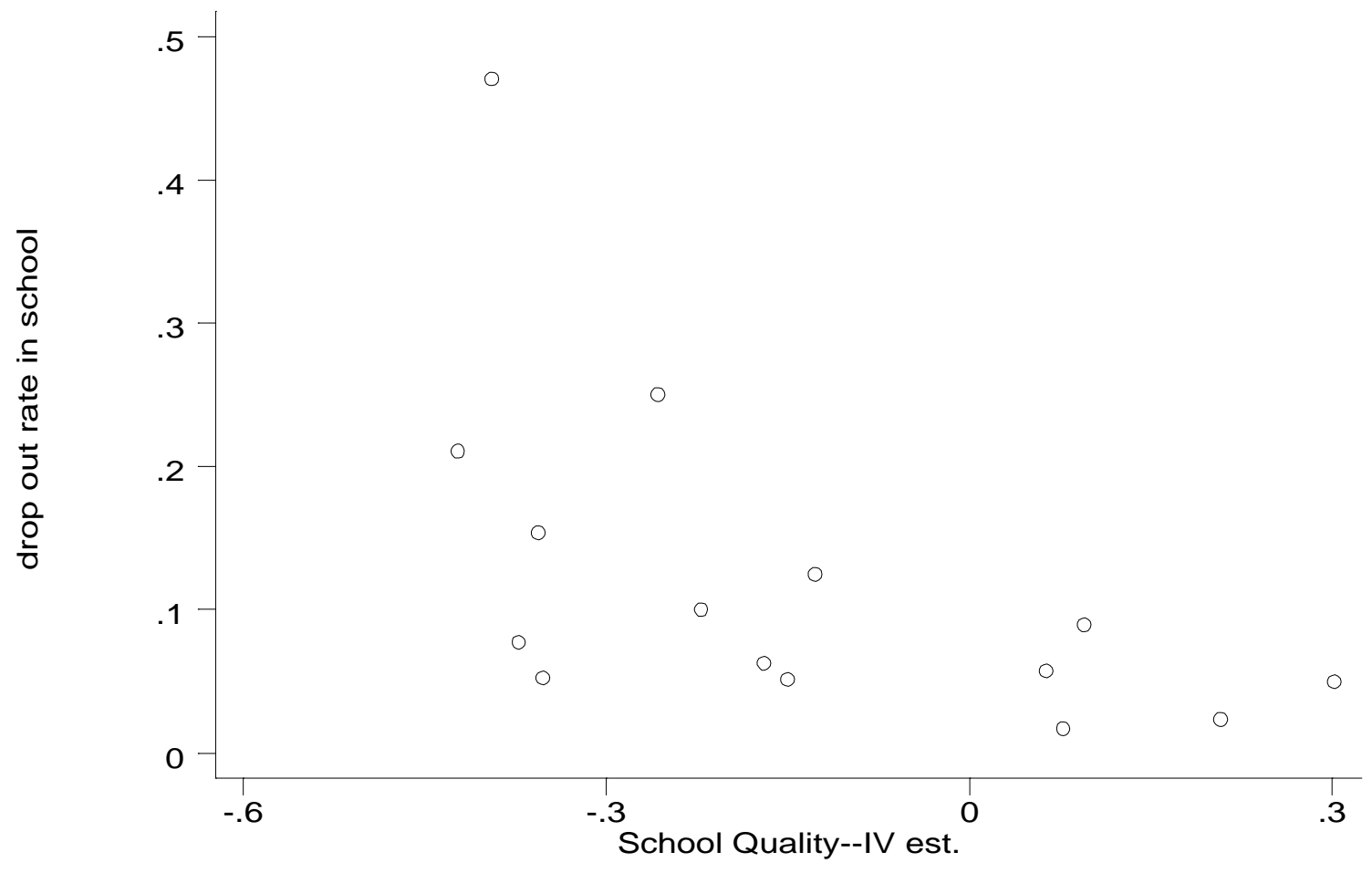


Perhaps the most novel feature of this estimation is the direct investigation of school quality $\left(\delta_{s}\right)$ on dropout behavior. These results suggest strongly that high quality schools in and of themselves serve to retain students and to prevent dropouts. Independent of the student's own achievement and ability level, better schools directly increase the probability that a student will stay in school. School quality is separately estimated and not based on simple survey questions about perceptions, but the evidence does indicate that parents and children can observe quality differences and find them important. Moreover, it must be emphasized that school quality is estimated from value-added models so that this effect is not the result of confusion with better students.

The models indicate that males are less likely to drop out of school, a finding that is totally unsurprising in Egypt. Egypt's Muslim society has traditionally had lower schooling for females along with less labor market attachment and lower wages if working. Other things equal, males are 0.06 less likely to drop out during elementary grades than females.

The grade dummy variables are included to indicate the overall probability of dropping out, conditional upon reaching any given grade. (The left out category is grade 3 ). Other things equal, as a student progresses past grade three, dropout probabilities steadily increase.

Somewhat surprisingly, individual drop out rates do not appear to be very sensitive to parental education levels. Mother's and father's years of schooling were insignificant by conventional standards. Higher levels of father's education are consistently related to lower dropout rates, but the point estimates are very small; mother's education uniformly shows a small and very insignificant impact on dropouts. This result is quite different from that of Lillard and Willis (1994) who find strong intergenerational transmission of schooling differences in their analysis of Malaysian schooling. It is clear that average schooling levels of parents in our Egyptian sample is very low and displays little variation. Note, however, that the models also condition on earlier achievement, $\mathrm{A}_{\mathrm{t}-1}$, and that this will incorporate differences in learning in the family. 
Table 3. Determinants of Dropout Behavior (MLE)

\begin{tabular}{|c|c|c|}
\hline Input & (1) & (2) \\
\hline$\delta_{\mathrm{S}}$ (school quality) & $\begin{array}{c}-3.81 \\
(-5.10)\end{array}$ & $\begin{array}{c}-3.82 \\
(-5.08)\end{array}$ \\
\hline LnABILITY $_{\mathrm{t}-1}$ & & $\begin{array}{c}.048 \\
(0.50)\end{array}$ \\
\hline LnACHIEVE $_{\mathrm{t}-1}$ & $\begin{array}{c}-.646 \\
(-5.96)\end{array}$ & $\begin{array}{c}-.647 \\
(5.95)\end{array}$ \\
\hline Grade 4 & $\begin{array}{c}.86 \\
(3.73)\end{array}$ & $\begin{array}{c}0.86 \\
(3.73)\end{array}$ \\
\hline Grade 5 & $\begin{array}{c}1.38 \\
(5.22)\end{array}$ & $\begin{array}{c}1.38 \\
(5.20)\end{array}$ \\
\hline Mother's Education & $\begin{array}{c}.038 \\
(0.46)\end{array}$ & $\begin{array}{c}.039 \\
(0.47)\end{array}$ \\
\hline Father's Education & $\begin{array}{l}-.044 \\
-1.36\end{array}$ & $\begin{array}{c}-.044 \\
(-1.36)\end{array}$ \\
\hline male & $\begin{array}{c}-.322 \\
(-1.85)\end{array}$ & $\begin{array}{c}-.322 \\
(-1.85)\end{array}$ \\
\hline wealth & $\begin{array}{c}.151 \\
(0.37)\end{array}$ & $\begin{array}{c}.152 \\
(0.37)\end{array}$ \\
\hline Constant & $\begin{array}{c}-.265 \\
(-0.58)\end{array}$ & $\begin{array}{c}-.267 \\
(-0.58)\end{array}$ \\
\hline correlation $(\mathrm{u}, \mathrm{v})$ & $\begin{array}{l}-.0096 \\
(-.097)\end{array}$ & $\begin{array}{l}-.0098 \\
(-.098)\end{array}$ \\
\hline observations & 1714 & 1714 \\
\hline
\end{tabular}


It is interesting to see how individual skills enter into the decision. Higher achievement lessens the probability of dropping out, while measured ability has essentially no effect on dropout behavior. ${ }^{23}$ The Ben-Porath-like neutrality assumption, often employed in modeling human capital investment decisions, indicates that human capital has equal return in producing more human capital or in market returns. The estimates here (combined with Table 4) suggest larger schooling returns than market returns of achievement, at least at early grades. Measured ability, on the other hand, appears "neutral."

Finally, family wealth differences have an insignificant effect on dropout decisions. While very imprecisely measured, ${ }^{24}$ this appears to indicate that borrowing constraints are not overly important in determining school continuation.

\section{The Market Value of Schooling and Achievement}

The underlying theory of school choice considers trading off foregone earnings for enhanced skills. As modified here, it concentrates on the marginal impact of varying quality, measured by student achievement (and the expectation of enhanced achievement from quality). A key issue is whether or not measured achievement is related to labor market outcomes. A secondary issue is whether or not any of this makes a difference for the young dropouts and students of the Egyptian sample. In order to address these issues, we estimate a series of simple earnings generating functions.

The earnings estimation relies on actual pay and characteristics for a sample of working children drawn from all old dropouts (1979 or earlier) and all new dropouts (1979-80) who have usable achievement and other basic data. The total sample of 3,051 dropouts yields 648 individuals work for

\footnotetext{
${ }^{23}$ Achievement and ability are measured in 1979, prior to the decision to drop out or remain in school in 1980 . It is still possible, however, that causality is confused in some instances. If a student stopped studying in school or simply did not try hard to complete the tests in anticipation of dropping out in 1980, dropout behavior could lead to lower achievement. It seems doubtful, however, that this is a major problem.

${ }^{24}$ Family wealth is measured by the proportion of the following items: running water, electricity, radio, reading material, and home ownership. Because these crude measures of wealth might have different meanings in urban and rural settings, the effect of wealth was estimated separately for urban and rural areas.
} 
pay in the formal market and provide information on labor market work and wages. The full dropout sample is used to estimate earnings functions and the probability of market work. Of those engaged in market work, forty-six percent are urban children, their mean age is 13 years, on average they have been out school for about four years when observed in 1980, and most of them ( 85 percent) are males. The urban and rural components in this sample have the same age and sex means, but the urban children have more years of schooling attained, staying in school one more year than their rural counterparts, and their mean score on the ability tests is 22 , twice that of rural children (11). The mean wage rate is 38.4 piaster a day, and it is larger in rural areas (36.1) than in urban areas (32.8).

In all of the analysis, the sample of young workers is stratified into urban and rural samples in order to capture fundamental differences in the structure of the labor markets. In part of the analysis, the urban sample is further subdivided into the Cairo area and the remaining urban areas of the country, although, because the samples get very small, we concentrate on the basic rural-urban split of the samples. For each stratification, a common log-linear earnings function is estimated. Table 4 presents the basic earnings estimates using OLS techniques for the sample of all working dropouts in $1980 .^{25}$

The models explain a relatively low portion of the overall variance in wages, perhaps because of significant measurement error in the wage rates themselves. Nevertheless, while imprecisely estimated, the wage parameters are quite consistent with expectations. Even for this young and inexperienced group of workers, it is possible to identify several key relationships and, particularly, the effects of schooling.

The estimates indicate that males consistently earn some 33-42 percent more than females in market work for pay. This differential is quite similar across urban and rural areas, although the premium

\footnotetext{
${ }^{25}$ These earnings models have been estimated jointly with models of the probability that any dropout works for wages in the market. These models, estimated by maximum likelihood techniques assuming normally distributed errors, are very imprecisely estimated. While the probability of market work can be characterized in a reasonable manner, the earnings relationships are not well estimated in this joint manner. Further, these estimation problems appear to be more than simple identification problems for the probability and earnings models but instead reflect the small samples and correlations among the variables.
} 
Table 4. Income Models -- All Working Dropouts

\begin{tabular}{|c|c|c|c|c|}
\hline \multirow{2}{*}{ Variable } & \multirow{2}{*}{ Rural } & \multicolumn{3}{|c|}{ Urban } \\
\hline & & Total & Cairo & $\begin{array}{l}\text { Non- } \\
\text { Cairo }\end{array}$ \\
\hline Male & $\begin{array}{r}0.422 \\
(4.5)\end{array}$ & $\begin{array}{r}0.333 \\
(2.2)\end{array}$ & $\begin{array}{r}-0.018 \\
(-0.1)\end{array}$ & $\begin{array}{r}0.641 \\
(2.8)\end{array}$ \\
\hline LnACHIEVE & $\begin{array}{r}0.024 \\
(0.7)\end{array}$ & $\begin{array}{r}0.107 \\
(2.6) \\
\end{array}$ & $\begin{array}{r}0.069 \\
(1.4) \\
\end{array}$ & $\begin{array}{r}0.144 \\
(2.0) \\
\end{array}$ \\
\hline $\begin{array}{l}\text { Highest } \\
\text { Grade }\end{array}$ & $\begin{array}{r}0.050 \\
(1.4)\end{array}$ & $\begin{array}{r}0.122 \\
(2.5)\end{array}$ & $\begin{array}{r}0.187 \\
(2.8)\end{array}$ & $\begin{array}{r}0.086 \\
(1.2)\end{array}$ \\
\hline $\begin{array}{l}\text { Experience } \\
\text { (time out of } \\
\text { school) }\end{array}$ & $\begin{array}{r}0.033 \\
(1.2)\end{array}$ & $\begin{array}{r}0.022 \\
(0.7)\end{array}$ & $\begin{array}{r}0.082 \\
(1.9)\end{array}$ & $\begin{array}{c}0.010 \\
(0.18)\end{array}$ \\
\hline Constant & $\begin{array}{r}2.804 \\
(12.9) \\
\end{array}$ & $\begin{array}{r}2.451 \\
(7.6) \\
\end{array}$ & $\begin{array}{r}2.444 \\
(5.7) \\
\end{array}$ & $\begin{array}{r}2.218 \\
(4.7) \\
\end{array}$ \\
\hline $\mathrm{R}^{2}$ & 0.08 & 0.07 & 0.08 & 0.09 \\
\hline observations & 348 & 297 & 151 & 146 \\
\hline
\end{tabular}


appears largest in rural areas. The gender differential is very imprecisely estimated in the small Cairo sample, although the nonCairo urban sample suggests even larger male-female differences. Interestingly, from an F-test for homogeneity of coefficients, once the level differences are accounted for with the gender dummy variable, the models are insignificantly different for the earnings of boys and of girls.

In neither urban or rural settings is it possible to detect an experience (time since dropout) effect. The estimated relationship with experience is generally small and statistically insignificant, although the effects in Cairo may be larger. The point estimates for the Cairo labor market indicate an 8 percent premium for each year of experience outside of school but this is considerably above any of the other estimates. $^{26}$

The key to the models for our purposes is the interaction of earnings and schooling. This interaction is found along both the quality (achievement) and the schooling quantity (highest grade) margins. In quality terms, achievement differences are directly translated into earnings differences in urban areas. Perhaps the most notable difference between the urban and rural settings is that there apparently is not a premium paid for more cognitive skills in rural areas. This finding would be consistent with a labor market situation where urban jobs were more skilled and where rural jobs were weighted toward manual labor.

More years of schooling yield higher immediate earnings to dropouts — quite clearly so in urban areas. An additional year of schooling is associated with 12 percent higher earnings in urban areas and 5 percent higher earnings in rural areas. The rural earnings effect is, however, imprecisely estimated and is not statistically significant.

\footnotetext{
${ }^{26}$ Note, however, that we do not have actual labor market experience. Instead we simply have time since dropped out of school. In the Cairo area, where work in the labor market is more likely for these drop outs, the estimated effect could be closer to an actual experience premium. In other words, measurement error for actual experience in the other labor markets may bias their coefficients toward zero.
} 
These earnings models provide overall support for the basic perspective of this analysis. Both quality and quantity of schooling are important, and the dropout decisions of primary school children could be strongly affected by estimates of school quality.

\section{Conclusions}

A simple set of conclusions stands out in this analysis. Higher skilled individuals - children with greater achievement — tend to be the ones who stay in school. Lower skilled individuals tend to leave school early.

But, holding constant the individual's own ability and achievement, a student attending a higher quality school will tend to stay in school. A student attending a lower quality school is more likely to drop out and complete fewer grades. Students recognize quality differences and act on them. Bringing all schools up to the best quality school would reduce the dropout rate estimated in the sampled Egyptian schools by two-thirds or more.

Of course, making such quality adjustments may be difficult because this analysis has not identified the specific school factors that add up to variations in school quality. Overall school quality could include some combination of teacher and administrator quality; school-specific factors including textbooks, conditions of the plant, and so forth; or school peers. The limited analysis here did not suggest that common measures of school or teacher characteristics or of peers were very powerful indicators of overall school quality. For our purposes, the source is not particularly important, but for policy purposes it would be. Unfortunately, the evidence about specific factors influencing school quality is not very 
precise (see Hanushek (1995, (2003), Glewwe and Kremer (2006)). This ambiguity about policy pervades both developing and developed countries, and is not resolved here. ${ }^{27}$

For similar reasons, we also have not estimated the cost that might be incurred in adjusting school quality. Nevertheless, the economic importance of improving school quality in countries with poor educational outcomes is very clear (Hanushek and Wößmann (2006)).

The finding about the effects of school quality on completion rates provides more evidence that the frequently discussed equity-quality trade-off is misstated. The trade-off typically identified arises from simple consideration of the budget constraint facing schools; money spent on quality reduces that available for expanding the number of school positions available. This simple budget analysis, however, ignores the complementarity of quality and efficiency in production.

Quality interactions with individual student decisions about leaving school have important implications for conventional analyses of school investment. Standard rate of return calculations based solely on quantity of schooling are likely to be misleading because they ignore school quality which improves earnings opportunities and which is positively correlated with quantity completed by individuals. The rate of return to pure quantity of schooling is almost certainly overestimated when quality is ignored, implying that standard policy prescriptions based on just simple quantity returns might lead to suboptimal policies. ${ }^{28}$ For example, a policy of significant expansion of schooling made budgetarily viable by expanding poor quality schools might never yield the gains forecast by standard rate of return estimates. The optimal policy given feedback of quality to school completion depends on the costs of improving quality, something that is unknown given uncertainties about how to improve quality.

\footnotetext{
${ }^{27}$ While outside the scope of this study, the obvious direction of policy involves heavier reliance on performance incentives. The case for these, and the outlines of potential policies, can be found in Hanushek and others (1994) for the U.S., in Lavy (2002) for Israel, and in Glewwe and Kremer (2006) for a sampling of developing countries. ${ }^{28}$ Hanushek and Zhang (2006) provide international estimates on how recognition of quality differences systematically lowers the estimates of the impact of school attainment on earnings. For a broader interpretation of common Mincer equations to estimate the return to years of schooling, see Heckman, Lochner, and Todd (2006).
} 
While this analysis has not been able to consider repetition because of the sample design, the effects of quality on repetition are likely to reinforce these results. Lower quality schools tend to retain students in grade - because they have not accomplished as much as they progress through school (see Harbison and Hanushek (1992) and Gomes-Neto and Hanushek (1994)). Grade repetition then limits overall access to schools, because repeaters are taking up positions in schools that could otherwise be used by an expanded group of students. In simplest terms, if noncompletion of primary schooling is a concern in developing countries, as it should be, school improvement may be an attractive policy.

The Education for All initiative has been primarily aimed at achieving universal primary schooling, although it has recognized the quality of schooling is also an issue (UNESCO (2005)). It has not, however, seen that there is a direct linkage of quality and achievement of its attainment goals. In fact, the strategy for school expansion in developing countries might be quite different if these linkages were recognized and incorporated in planning and policies.

These perspectives on school quality and school completion may also have implications for developed countries. For example, no systematic analysis relates drop out behavior to school quality in the United States. Moreover, most policy discussions completely ignore such linkages, implying instead that drop out behavior is largely an irrational individual decision. ${ }^{29}$

Finally, from an analytical perspective, this paper demonstrates the importance of incorporating outcome-based measures of school quality. This analysis separates individual achievement from the expected achievement gains attributable to an individual school. By doing this, it circumvents the serious problems that come with measuring school quality by a selected group of inputs, and it avoids confusing school quality with individual differences in performance that might arise from other sources.

\footnotetext{
${ }^{29}$ One investigation of parental choice and school quality is found in the case of exit behavior from charter schools in the U.S. Hanushek, Kain, Rivkin, and Branch (forthcoming) show that parents are much more likely to leave low quality (i.e., high value added) charter schools than high quality ones.
} 


\section{References}

Altonji, Joseph G., and Charles R. Pierret. 2001. "Employer learning and statistical discrimination." Quarterly Journal of Economics 116,no.1 (February):313-350.

Angrist, Joshua D., and Victor Lavy. 1997. "The effect of a change in language of instruction on the returns to schooling in Morocco." Journal of Labor Economics 15:S48-S76.

Barro, Robert J. 1991. "Economic growth in a cross section of countries." Quarterly Journal of Economics 106,no.2 (May):407-443.

_. 2001. "Human capital and growth." American Economic Review 91,no.2 (May):12-17.

Becker, Gary S. 1975. "Human Capital: A Theoretical and Empirical Analysis, With Special Reference to Education. New York: National Bureau of Economic Research.

Behrman, Jere R., and Nancy Birdsall. 1983. "The quality of schooling: quantity alone is misleading." American Economic Review 73,no.5 (December):928-946.

Behrman, Jere R., David Ross, and Richard Sabot. forthcoming. "Improving the quality versus increasing the quantity of schooling: Estimates of rates of return from rural Pakistan." Journal of Development Economics.

Ben-Porath, Yoram. 1970. "The Production of Human Capital Over Time." In Education, Income and Human Capital, edited by W. Lee Hansen. New York: National Bureau of Economic Research:129-147.

Betts, Julian R. 1996. "Is there a link between school inputs and earnings? Fresh scrutiny of an old literature." In Does money matter? The effect of school resources on student achievement and adult success, edited by Gary Burtless. Washington, DC: Brookings:141-191.

Bishop, John. 1989. "Is the test score decline responsible for the productivity growth decline?" American Economic Review 79,no.1:178-197.

_ 1991. "Achievement, test scores, and relative wages." In Workers and their wages, edited by Marvin H. Kosters. Washington, DC: The AEI Press:146-186.

Blackburn, McKinley L., and David Neumark. 1993. "Omitted-ability bias and the increase in the return to schooling." Journal of Labor Economics 11,no.3 (July):521-544.

-1995. "Are OLS estimates of the return to schooling biased downward? Another look." Review of Economics and Statistics 77,no.2 (May):217-230.

Boissiere, Maurice X., John B. Knight, and Richard H. Sabot. 1985. "Earnings, schooling, ability, and cognitive skills." American Economic Review 75,no.5:1016-1030. 
Bosworth, Barry P., and Susan M. Collins. 2003. "The empirics of growth: An update." Brookings Papers on Economic Activity 2003,no.2:113-206.

Card, David. 1999. "Causal effect of education on earnings." In Handbook of labor economics, edited by Orley Ashenfelter and David Card. Amsterdam: North-Holland:1801-1863.

Card, David, and Alan B. Krueger. 1992. "Does school quality matter? Returns to education and the characteristics of public schools in the United States." Journal of Political Economy 100,no.1 (February):1-40.

Coulombe, Serge, Jean-François Tremblay, and Sylvie Marchand. 2004. Literacy scores, human capital and growth across fourteen OECD countries. Ottawa: Statistics Canada

Glewwe, Paul. 1996. "The relevance of standard estimates of rates of return to schooling for educational policy: A critical assessment." Journal of Development Economics 51:267290.

Glewwe, Paul, and Michael Kremer. 2006. "Schools, teachers, and educational outcomes in developing countries." In Handbook of the Economics of Education, edited by Eric A. Hanushek and Finis Welch. Amsterdam: North Holland:943-1017.

Gomes-Neto, João Batista, and Eric A. Hanushek. 1994. "Causes and consequences of grade repetition: Evidence from Brazil." Economic Development and Cultural Change 43,no.1 (October):117-148.

Griliches, Zvi. 1977. "Estimating the returns to schooling: Some econometric problems." Econometrica 45,no.1:1-22.

Grogger, Jeffrey T., and Eric Eide. 1993. "Changes in college skills and the rise in the college wage premium." Journal of Human Resources 30,no.2 (Spring):280-310.

Hanushek, Eric A. 1979. "Conceptual and empirical issues in the estimation of educational production functions." Journal of Human Resources 14,no.3 (Summer):351-388.

. 1992. "The trade-off between child quantity and quality." Journal of Political Economy 100,no.1 (February):84-117.

_. 1995. "Interpreting recent research on schooling in developing countries." World Bank Research Observer 10,no.2 (August):227-246.

- 2002. "Publicly provided education." In Handbook of Public Economics, edited by Alan J. Auerbach and Martin Feldstein. Amsterdam: Elsevier:2045-2141.

— 2003. "The failure of input-based schooling policies." Economic Journal 113,no.485 (February):F64-F98.

Hanushek, Eric A., John F. Kain, Steve G. Rivkin, and Gregory F. Branch. forthcoming. "Charter school quality and parental decision making with school choice." Journal of Public Economics. 
Hanushek, Eric A., and Dennis D. Kimko. 2000. "Schooling, labor force quality, and the growth of nations." American Economic Review 90,no.5 (December):1184-1208.

Hanushek, Eric A., and with others. 1994. Making schools work: Improving performance and controlling costs. Washington, DC: Brookings Institution.

Hanushek, Eric A., Steven G. Rivkin, and Lori L. Taylor. 1996. "Aggregation and the estimated effects of school resources." Review of Economics and Statistics 78,no.4 (November):611-627.

Hanushek, Eric A., and Ludger Wößmann. 2006. "The Role of School Improvement in Economic Development." mimeo,

Hanushek, Eric A., and Lei Zhang. 2006. "Quality Consistent Estimates of International Returns to Skill." National Bureau of Economic Research, WP12664, Cambridge, MA, NBER (November).

Harbison, Ralph W., and Eric A. Hanushek. 1992. Educational performance of the poor: lessons from rural northeast Brazil. New York: Oxford University Press.

Heckman, James J., Anne Layne-Farrar, and Petra Todd. 1996. "Human capital pricing equations with an application to estimating the effect of schooling quality on earnings." Review of Economics and Statistics 78,no.4 (November):562-610.

Heckman, James J., Lance J. Lochner, and Petra E. Todd. 2006. "Earnings functions, rates of return and treatment effects: The Mincer equation and beyond." In Handbook of the Economics of Education, edited by Eric A. Hanushek and Finis Welch. Amsterdam: North Holland:307-458.

Jamison, Eliot A., Dean T. Jamison, and Eric A. Hanushek. 2006. "The effects of education quality on mortality decline and income growth." Dijon, France, International Conference on the Economics of Education (June 20-23).

Jolliffe, Dean. 1998. "Skills, schooling, and household income in Ghana." World Bank Economic Review 12:81-104.

Knight, John B., and Richard H. Sabot. 1990. Education, productivity, and inequality. New York: Oxford University Press.

Lavy, Victor. 2002. "Evaluating the effect of teachers' group performance incentives on pupil achievement." Journal of Political Economy 110,no.6 (December):1286-1317.

Lazear, Edward P. 2003. "Teacher incentives." Swedish Economic Policy Review 10,no.3:179214.

Lillard, Lee A., and Robert J. Willis. 1994. "Intergenerational educational mobility: Effects of family and state in Malaysia." Journal of Human Resources 24,no.4 (Fall):1126-1166.

Lucas, Robert E. 1988. "On the mechanics of economic development." Journal of Monetary Economics 22(July):3-42. 
Moll, Peter G. 1998. "Primary schooling, cognitive skills, and wage in South Africa." Economica 65:263-284.

Mulligan, Casey B. 1999. "Galton versus the human capital approach to inheritance." Journal of Political Economy 107,no.6, pt. 2 (December):S184-S224.

Murnane, Richard J., John B. Willett, M. Jay Braatz, and Yves Duhaldeborde. 2001. "Do different dimensions of male high school students' skills predict labor market success a decade later? Evidence from the NLSY." Economics of Education Review 20,no.4 (August):311-320.

Murnane, Richard J., John B. Willett, Yves Duhaldeborde, and John H. Tyler. 2000. "How important are the cognitive skills of teenagers in predicting subsequent earnings?" Journal of Policy Analysis and Management 19,no.4 (Fall):547-568.

Murnane, Richard J., John B. Willett, and Frank Levy. 1995. "The growing importance of cognitive skills in wage determination." Review of Economics and Statistics 77,no.2 (May):251-266.

Neal, Derek A., and William R. Johnson. 1996. "The role of pre-market factors in black-white differences." Journal of Political Economy 104,no.5 (October):869-895.

O'Neill, June. 1990. "The role of human capital in earnings differences between black and white men." Journal of Economic Perspectives 4,no.4 (Fall):25-46.

Psacharopoulos, George. 1994. "Returns to investment in education: A global update." World Development 22:1325-1344.

Psacharopoulos, George, and Harry A. Patrinos. 2004. "Returns to investment in education: a further update." Education Economics 12,no.2 (August):111-134.

Rivkin, Steven G. 2005. "Cumulative Nature of Learning and Specification Bias in Education Research." mimeo, Amherst College (

Romer, Paul. 1990. "Endogenous technological change." Journal of Political Economy 99,no.5,pt. II:S71-S102.

Swanson, Eric V. 1988. Achievement and wastage: An econometric analysis of the retention of basic skills in a developing country, State University of New York at Buffalo, Buffalo.

UNESCO. 2005. Education for all: The quality imperative, EFA Global Monitoring Report. Paris: UNESCO.

United Nations. 2004. Millennium Development Goals: Second Country Report, Egypt. United Nations

Vijverberg, Wim P.M. 1999. "The impact of schooling and cognitive skills on income from nonfarm self-employment." In The economics of school quality investments in developing countries: An empirical study of Ghana, edited by Paul Glewwe. New York: St. Martin's Press (with University of Oxford). 
Willis, Robert J. 1986. "Wage determinants: A survey and reinterpretation of human capital earnings functions." In Handbood of labor economics, edited by Orley Ashenfelter and Richard Layard. Amsterdam: North-Holland:525-602.

Willis, Robert J., and Sherwin Rosen. 1979. "Education and self-selection." Journal of Political Economy 87:S65-S98.

World Bank. 1991. Egypt: A social security analysis. Washington: World Bank

- 2002. Arab Republic of Egypt -- Education Sector Review: Progress and Priorities for the Future. Washington: World Bank (October).

Wößmann, Ludger. 2002. Schooling and the Quality of Human Capital Berlin: Springer. 2003. "Specifying human capital." Journal of Economic Surveys 17,no.3 (July):239-270. 
Table A1: Descriptive Statistics for Analytical Samples

A. MLE School Quality-Dropout Sample $(\mathrm{n}=1,714)$

\begin{tabular}{||l|c|c|l||}
\hline Variable & Mean & $\begin{array}{c}\text { Stand. } \\
\text { Dev. }\end{array}$ & Description \\
\hline \hline Grade 3 & .33 & .47 & $=1$ if student in grade 3; $=0$ otherwise \\
\hline Grade 4 &. .34 & .47 & $=1$ if student in grade 4; $=0$ otherwise \\
\hline Grade 5 & .33 & .47 & $=1$ if student in grade 5; $=0$ otherwise \\
\hline Grade 6 & 0 & 0 & $=1$ if student in grade 6; $=0$ otherwise \\
\hline male & .60 & .49 & $=1$ if student is male; $=0$ otherwise \\
\hline urban & .51 & .50 & $=1$ if student in urban school; $=0$ otherwise \\
\hline wealth & .59 & .22 & $\begin{array}{l}\text { proportion of the following items: running } \\
\text { water, electricity, radio, reading material, } \\
\text { and home ownership. }\end{array}$ \\
\hline $\begin{array}{l}\text { Father's } \\
\text { education }\end{array}$ & 1.84 & 4.2 & years of schooling \\
\hline $\begin{array}{l}\text { Mother's } \\
\text { education }\end{array}$ & .53 & 2.2 & years of schooling \\
\hline \hline
\end{tabular}

B. OLS School Quality Sample $(\mathrm{n}=2,431)$

\begin{tabular}{||l|c|c|l||}
\hline \hline Variable & Mean & $\begin{array}{c}\text { Stand. } \\
\text { Dev. }\end{array}$ & Description \\
\hline \hline $\begin{array}{l}\text { Achievement - } \\
1980\end{array}$ & $26.2^{\mathrm{a}}$ & 1.99 & $\begin{array}{l}\text { Raw test score on Reading A + Simple } \\
\text { Operations Tests - 1980 }\end{array}$ \\
\hline $\begin{array}{l}\text { Achievement - } \\
1979\end{array}$ & $20.8^{\mathrm{a}}$ & 2.05 & $\begin{array}{l}\text { Raw test score on Reading A + Simple } \\
\text { Operations Tests - 1979 }\end{array}$ \\
\hline Grade 4 & .42 & .49 & $=1$ if student in grade 4; $=0$ otherwise \\
\hline Grade 5 & .33 & .47 & $=1$ if student in grade 5; $=0$ otherwise \\
\hline Grade 6 & .20 & .40 & $=1$ if student in grade 6; $=0$ otherwise \\
\hline $\begin{array}{l}\text { Father's } \\
\text { education }\end{array}$ & 1.15 & 3.3 & years of schooling \\
\hline
\end{tabular}




\begin{tabular}{|l|l|l|l||}
\hline $\begin{array}{l}\text { Mother's } \\
\text { education }\end{array}$ & .32 & 1.7 & years of schooling \\
\hline
\end{tabular}

Note: a. geometric mean of achievement.

\section{Earnings Sample - Income Estimation}

\begin{tabular}{||l|c|c|c|c|c||}
\hline \multirow{2}{*}{ Variable } & \multicolumn{2}{|c|}{ Rural (n=348) } & \multicolumn{2}{|c||}{ Urban (n=297) } & \multirow{2}{*}{ Description } \\
\cline { 2 - 5 } & Mean & $\begin{array}{c}\text { Stnd } \\
\text { Dev. }\end{array}$ & Mean & $\begin{array}{c}\text { Stnd. } \\
\text { Dev. }\end{array}$ & \\
\hline \hline Male & .833 & .37 & .889 & .31 & $=1$ if male; $=0$ if female \\
\hline $\begin{array}{l}\text { Highest } \\
\text { grade }\end{array}$ & 4.81 & 1.08 & 5.03 & 1.07 & $\begin{array}{l}\text { Highest school grade } \\
\text { completed }\end{array}$ \\
\hline Experience & 4.43 & 1.31 & 3.58 & 1.63 & Years since left school \\
\hline $\begin{array}{l}\text { Achievement } \\
\text { - 1979 }\end{array}$ & $8.95^{\mathrm{a}}$ & 3.23 & $\begin{array}{c}15.59 \\
\mathrm{a}\end{array}$ & 3.21 & $\begin{array}{l}\text { Score on Reading A + } \\
\text { Simple Operations Tests - } \\
1979\end{array}$ \\
\hline Market wage & $\begin{array}{c}36.42 \\
\mathrm{a}\end{array}$ & 1.94 & $\begin{array}{c}41.85 \\
\mathrm{a}\end{array}$ & 2.29 & Income in piasters per day \\
\hline
\end{tabular}

Note: a. Geometric mean. 